\title{
Simple and Sensitive Procedure for Screening Collagenolytic Bacteria and the Isolation of Collagenase Mutants
}

\author{
By P. J. ROBBERTSE, * D. R. WOODS, A. H. REAY AND F. T. ROBB \\ Department of Microbiology, Rhodes University, Grahamstown 6140, South Africa
}

(Received 19 October 1977; revised 27 January 1978)

\section{INTRODUCTION}

Woods et al. (1973) described a procedure involving liquid cultures for determining the collagenolytic activity of hide bacterial populations. Previous reports have shown that the enumeration of aerobic and anaerobic cured hide bacteria is of limited value as an indication of hide quality (Woods et al., 1970a, b; Woods, Welton \& Cooper, 1971). However, a routine agar plate assay for collagenolytic bacterial colonies would be most useful in the leather industry and would have advantages over the liquid technique. The isolation from hides of an aerobic collagenolytic Achromobacter iophagus strain, which produces an inducible extracellular collagenase with the highest specific activity for a collagenase, has been described (Welton \& Woods, 1973, 1975; Lecroisey et al., 1975). Future studies on the control of collagenase could be facilitated by the development of a simple screening procedure for the isolation of collagenase mutants.

Although techniques utilizing reconstituted collagen gels have been used for the isolation of collagenolytic bacteria (Waldvogel \& Swartz, 1969; Merkel, Dreisbach \& Ziegler, 1975), they have proved unsuitable for mutant screening procedures. The method of Waldvogel \& Swartz (1969) involving the transfer of portions of agar covered by actively growing overnight cultures to collagen gels is not suitable for screening large numbers of colonies. Growth on collagen gels alone (Merkel et al., 1975) is also unsuitable because many strains, including A. iophagus, do not form visible colonies on collagen gels. This paper describes an adaptation of the double layered agar plate technique used for the detection of various enzymes (e.g. lipase: Eijkman, 1901; Alford \& Steinle, 1967) for the isolation of collagenase-producing strains. The characteristics of some of the mutants are also described.

\section{METHODS}

All percentage compositions are $\mathrm{w} / \mathrm{v}$ and all nutrients are from Difco, unless otherwise stated.

Bacteria. The wild-type collagenolytic A. iophagus strain isolated from hides by Welton \& Woods (1973) was used. The strain was identified as A. iophagus using the seventh edition of Bergey's Manual of Determinative Bacteriology (Breed, Murray \& Smith, 1957), but using the eighth edition (Buchanan \& Gibbons, 1974) it was found to be of uncertain taxonomic position.

Media. Wild-type and mutant strains were maintained on the complex medium of Welton \& Woods (1973). The peptone agar medium consisted of $0.25 \%$ peptone and $1.5 \%$ agar in $0.1 \mathrm{M}-\mathrm{Tris} / \mathrm{HCl}$ buffer $(\mathrm{pH} 7 \cdot 6)$ containing $0.4 \mathrm{M}-\mathrm{NaCl}$ and $2 \mathrm{mM}-\mathrm{CaCl}_{2}$. The Casamino acids medium consisted of $2.5 \%$ vitamin-free acidhydrolysed casein and $1.5 \%$ agar in similar Tris $/ \mathrm{HCl}$ buffer. The minimal medium was that of Grabow \& Smit (1967), supplemented with $0.4 \mathrm{M}-\mathrm{NaCl}$ and $2 \mathrm{mM}-\mathrm{CaCl}_{2}$. Incubation was at $30^{\circ} \mathrm{C}$.

Mutagenesis. Collagenase mutants were produced by treating exponentially growing broth cultures with $100 \mu \mathrm{g} N$-methyl- $N^{\prime}$-nitro- $N$-nitrosoguanidine (NTG) $\mathrm{ml}^{-1}$ for $15 \mathrm{~min}$ at $37^{\circ} \mathrm{C}$ (Adelberg, Mandel \& Chen, 1965 ) in $0.1 \mathrm{M}$-Tris/maleic acid buffer containing $0.4 \mathrm{M}-\mathrm{NaCl}, 0.4 \mathrm{mM}-\mathrm{MgSO}_{4}, 7.5 \mathrm{mM}-\left(\mathrm{NH}_{4}\right)_{2} \mathrm{SO}_{4}$ and $2 \mathrm{~mm}$-sodium citrate. The treated cultures were incubated in the peptone medium at $30^{\circ} \mathrm{C}$ for $4 \mathrm{~h}$ to allow the expression of mutations.

* Present address: Department of Genetics, University of Pretoria, Pretoria 0002, South Africa. 
Preparation of collagen. Acid-soluble calfskin collagen was prepared by the method of Cooper \& Davidson (1965) and kept in $0.47 \mathrm{M}$-acetic acid at $4{ }^{\circ} \mathrm{C}$. Prior to use, the collagen was clarified by centrifugation and dialysed against $0 \cdot 1 \mathrm{M}$-sodium phosphate buffer, $\mathrm{pH} 7 \cdot 6$. The collagen did not gel when it was kept at $4{ }^{\circ} \mathrm{C}$ and when required $4 \mathrm{M}-\mathrm{NaCl}$ was added to give a final concentration of $0.4 \mathrm{M}-\mathrm{NaCl}$. The collagen was immediately poured over the surface of the peptone agar plates and allowed to gel at $37^{\circ} \mathrm{C}$.

Screening of collagenase mutants. Peptone agar plates were spread with NTG-treated $A$. iophagus wild-type cells and incubated overnight at $30^{\circ} \mathrm{C}$. The colonies were then overlaid with the cold, reconstituted, acidsolubilized collagen which gelled on incubation at $37^{\circ} \mathrm{C}$. After a further 1.5 or $3 \mathrm{~h}$ incubation at $37^{\circ} \mathrm{C}$, collagenase-positive colonies were identified by a zone of hydrolysis around the colonies. The specificity of the reconstituted collagen gel overlay was tested by placing on the surface of the gel filter paper discs containing either pronase (Miles Laboratories), trypsin (Miles Laboratories) or collagenase from Clostridium histolyticum (Koch-Light). The effects of glucose and Casamino acids on the production of collagenase were determined by adding $0 \cdot 1,0.5,1 \cdot 0,1 \cdot 5,2.0$ or $2.5 \%$ glucose or Casamino acids to the peptone agar. In certain experiments either $1 \%$ glucose or $0 \cdot 1 \%$ Casamino acids was added to the collagen overlay.

Induction of collagenase in liquid media. The induction of collagenase in broth cultures of $A$. iophagus was investigated by adding collagen, peptone, gelatin, tryptone, Casitone and Casamino acids to $0 \cdot 1 \mathrm{M}-\mathrm{Tris} / \mathrm{HCl}$ buffer (pH 7.6) containing $0.4 \mathrm{M}-\mathrm{NaCl}$ and $2 \mathrm{mM}-\mathrm{CaCl}_{2}$. The cultures were shaken at $30^{\circ} \mathrm{C}$ for $18 \mathrm{~h}$ and collagenase was assayed using the synthetic substrate phenylazobenzyloxycarbonyl-L-prolyl-L-leucyl-glycyl-Lprolyl-D-arginine (PZ-Pro-Leu-Gly-Pro-Arg) (Fluka, Buchs, Switzerland) by the method of Wünsch \& Heidrich (1963). Collagenase activity was expressed as pkat per ml culture filtrate on the basis of $1 \mathrm{pkat}=0.09$ units according to Wünsch \& Heidrich (1963).

\section{RESULTS}

\section{Induction of collagenase}

Collagenase was induced by both collagen and peptone, giving activities of $60 \mathrm{pkat} \mathrm{ml}^{-1}$ in the presence of $2 \mathrm{mg}$ collagen $\mathrm{ml}^{-1}$ and 300 and $370 \mathrm{pkat} \mathrm{ml}^{-1}$ in the presence of 5 and $50 \mathrm{mg}$ peptone $\mathrm{ml}^{-1}$, respectively. Media containing gelatin, tryptone, Casitone or Casamino acids (each at $50 \mathrm{mg} \mathrm{ml}^{-1}$ ) and glucose minimal salts medium all failed to induce the production of collagenase. The amount of bacterial growth was similar in all the media except the collagen and glucose minimal salts media. Further incubation of all cultures which did not contain collagenase after $18 \mathrm{~h}$ did not result in the induction of collagenase. Since the peptone medium induced the highest yields of collagenase, it was used in the development of a plate method for screening collagenase mutants.

\section{Collagenase screening procedure}

The double layered agar plate technique using a peptone agar layer and collagen gel overlay was investigated as a method for screening collagenase strains and mutants. The collagen gel was not liquefied by either pronase or trypsin but was hydrolysed by commercial $C$. histolyticum collagenase. The method proved to be suitable for the detection of collagenasepositive $\left(\mathrm{Col}^{+}\right)$wild-type colonies of $A$. iophagus. The $\mathrm{Col}^{+}$colonies were surrounded by an area of hydrolysis and collagenase-negative $\left(\mathrm{Col}^{-}\right)$strains or mutants showed no zones of hydrolysis. A semi-quantitative estimation of the rate and amount of collagenase produced was obtained by determining the time and degree of collagen lysis. The wild-type $A$. iophagus strain produced zones of collagen hydrolysis on peptone plates after $1.5 \mathrm{~h}$ at $37^{\circ} \mathrm{C}$.

\section{Isolation of collagenase mutants}

The production of collagenase by the wild-type $\mathrm{Col}^{+}$strain was inhibited by the addition of either $0.5 \%$ glucose or $0.5 \%$ Casamino acids to the peptone agar (Table 1 ). The addition of $0.1 \%$ Casamino acids to the collagen overlay inhibited collagenase production by the $\mathrm{Col}^{+}$strain growing on peptone agar plates containing $0.1 \%$ Casamino acids. The inhibition of collagen hydrolysis by glucose was not reversed by the addition of $1 \mathrm{~mm}$-cyclic AMP. The $\mathrm{Col}^{+}$strain did not hydrolyse the collagen gel overlay after growth on the Casamino acids agar medium. The $\mathrm{Col}^{+}$strain was mutagenized with NTG and screened for mutants on the 
Table 1. Collagenase production by A. iophagus wild-type $\mathrm{Col}^{+}$strain and the mutant strains ColA, ColG and $\mathrm{Col}^{-}$

Peptone $(0.25 \%)$ or Casamino acids (CAA; $2.5 \%$ ) agar plates supplemented with different concentrations of glucose, cyclic AMP or CAA were streaked with the $\mathrm{Col}^{+}, \mathrm{ColA}, \mathrm{ColG}$ and $\mathrm{Col}^{-}$ A. iophagus strains. After overnight incubation at $30^{\circ} \mathrm{C}$, the plates containing visible colonies were overlaid with either collagen or collagen supplemented with $1 \%$ glucose or $0.1 \%$ CAA. Zones of hydrolysis were recorded after $3 \mathrm{~h}$ at $37^{\circ} \mathrm{C}$.

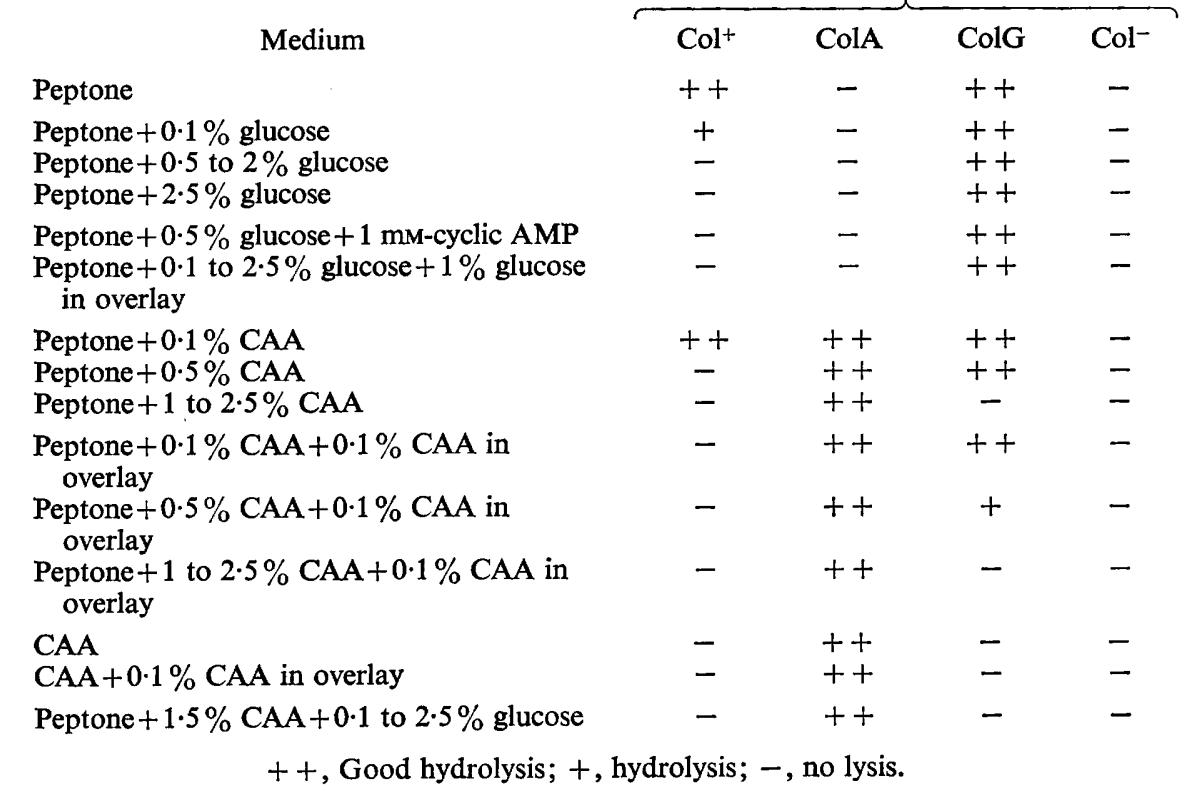

media indicated in Table 1. Many $\mathrm{Col}^{-}$mutants were isolated and the nature of the mutations are being investigated.

Two mutants, a ColA mutant and a ColG mutant (Table 1), were isolated which differed from the $\mathrm{Col}^{+}$strain in their sensitivity to repression of collagenase by Casamino acids and glucose, respectively. The ColA mutant was not only completely insensitive to the addition of $2.5 \%$ Casamino acids to the peptone agar and $0.1 \%$ Casamino acids to the collagen overlay, but actually required the addition of at least $0.1 \%$ Casamino acids to the peptone agar before collagenase was produced. Optimum levels of collagenase were obtained when $1.5 \%$ Casamino acids was added to the peptone agar. The production of collagenase by the ColA mutant in peptone agar supplemented with $1.5 \%$ Casamino acids was not repressed by the addition of 0.1 to $2.5 \%$ glucose to the agar medium. The ColG mutant was repressed by concentrations of Casamino acids greater than $0.5 \%$ but was not affected by glucose. Although many colonies have been screened, a constitutive mutant which does not require collagen or peptone for collagenase induction has not been isolated.

\section{DISCUSSION}

The peptone-collagen overlay method is a simple, sensitive and specific procedure for the isolation of collagenase strains or mutants. The method could be used in the leather and related industries as a quality control procedure for assaying collagenolytic bacteria on hides and skins.

The induction of collagenase by peptone and not gelatin is interesting. Keil-Dlouha, Misrahi \& Keil (1976) showed that the synthesis of collagenase in $A$. iophagus is induced by 
collagen and by its high molecular weight fragments. It is concluded that peptone contains the high molecular weight fragments but that gelatin, although it is a degradation product of collagen, does not contain the inducer.

The production of collagenase by the wild-type $A$. iophagus strain is repressed by both glucose and Casamino acids. The failure of cyclic AMP to reverse the glucose effect suggests that this effect is not due to catabolite repression (De Crombrugghe et al., 1969). The isolation of the ColG mutant, which is insensitive to glucose but repressed by amino acids, and the ColA mutant, which is insensitive to glucose but requires amino acids, suggests that the glucose and amino acid effects are mediated differently. The repression of extracellular protease synthesis by amino acids has been reported in a number of bacterial genera (Glenn, 1976). However, little is known about the mechanism of repression by amino acids. This study reveals a complex regulatory system for collagenase involving two independent inhibitory effects and a separate inductive effect by collagen and its high molecular weight fragments. The mechanisms of these three systems are unknown and are being investigated.

D.R.W. and P.J.R. acknowledge research grants from the South African Council of Scientific and Industrial Research.

\section{REFERENCES}

Adelberg, E. A., Mandel, M. \& Chen, G. C. C. (1965). Optimal conditions for mutagenesis by $N$-methyl- $N^{\prime}$-nitro- $N$-nitrosoguanidine in Escherichia coli $\mathrm{k} 12$. Biochemical and Biophysical Research Communications 18, 788-795.

Alford, J. A. \& Steinle, E. E. (1967). A double layered plate method for the detection of microbial lipolysis. Journal of Applied Bacteriology 30, 488-494.

Breed, R. S., Murray, E. G. D. \& SMith, N. R. (editors) (1957). Bergey's Manual of Determinative Bacteriology, 7th edn. Baltimore: Williams \& Wilkins.

Buchanan, R. E. \& Gibbons, N. E. (editors) (1974). Bergey's Manual of Determinative Bacteriology, 8th edn. Baltimore: Williams \& Wilkins.

CoOper, D. R. \& DAVidson, R. J. (1965). The effect of ultraviolet irradiation on soluble collagen. Biochemical Journal 97, 139-147.

De Crombrugghe, B., Perlman, R. L., Varmus, H. E. \& Pastan, I. R. A. (1969). Regulation of inducible enzyme synthesis in Escherichia coli by cyclic adenosine 3',5'-monophosphate. Journal of Biological Chemistry 244, 5828-5835.

EujKmaN, C. (1901). Über Enzyme bei Bakterien und Schimmelpilzen. Centralblatt für Bakteriologie, Parasitenkunde und Infektionskrankheiten 29, 841-848.

GlenN, A. R. (1976). Production of extracellular proteins by bacteria. Annual Review of Microbiology 30, 41-62.

GraBow, W. O. K. \& SMIT, J. A. (1967). Methionine synthesis in Proteus mirabilis. Journal of General Microbiology 46, 47-57.

KeIL-Dlouha, V., Misrahi, R. \& KeIL, B. (1976). The induction of collagenase and a neutral proteinase by their high molecular weight substrates in Achromobacter iophagus. Journal of Molecular Biology 107, 293-305.

Lecroisey, A., KeIl-Dlouha, V., Woods, D. R., Perrin, D. \& KeIL, B. (1975). Purification, stability and inhibition of the collagenase from Achromobacter iophagus. FEBS Letters 59, 167-172.

Merkel, J. R., Dreisbach, J. H. \& Ziegler, H. B. (1975). Collagenolytic activity of some marine bacteria. Applied Microbiology 29, 145-151.

Waldvogel, F.A. \& Swartz, M. N. (1969). Collagenolytic activity of bacteria. Journal of Bacteriology 98, 662-667.

WeLtoN, R. L. \& Woods, D. R. (1973). Halotolerant collagenolytic activity of Achromobacter iophagus. Journal of General Microbiology 75, 191-196.

Welton, R. L. \& Woods, D. R. (1975). Collagenase production by Achromobacter iophagus. Biochimica et biophysica acta 384, 228-234.

Woods, D. R., Atkinson, P., Cooper, D. R. \& Galloway, A. C. $(1970 a)$. The microbiology of curing and tanning processes. II. Analysis of aerobic bacteria in static hide brining. Journal of the American Leather Chemists' Association 65, 164-175.

Woods, D. R., Atkinson, P., Cooper, D. R. \& Galloway, A. C. $(1970 b)$. The microbiology of curing and tanning processes. III. Analysis of aerobic bacteria in agitated hide brining. Journal of the American Leather Chemists' Association 65, 410-418.

Woods, D. R., Welton, R. L. \& Cooper, D. R. (1971). The microbiology of curing and tanning processes. V. Anaerobic studies on halophobic and halophilic bacteria from cured hides. Journal of the American Leather Chemists' Association 66, 496-503.

Woods, D. R., Rawlings, D. E., Cooper, D. R. \& Galloway, A. C. (1973). Collagenolytic activity of hide bacteria and leather decay. Journal of Applied Bacteriology 36, 289-295.

WüNSCH, E. \& HeIDRICH, H. G. (1963). Zur quantitativen Bestimmung der Kollagenase. HoppeSeyler's Zeitschrift für physiologische Chemie 333, 149-151. 